\title{
Prevalence of Helicobacter pylori infection in the general adult population of the province of Ourense
}

\author{
R. Macenlle García, P. Gayoso Diz ${ }^{1}$, R. A. Sueiro Benavides² and J. Fernández Seara \\ Department of Digestive Medicine. 'Department of Research. Complejo Hospitalario de Ourense, Spain \\ ${ }^{2}$ Laboratory of Microbiology. Institute for Research and Food Analysis. Universidad de Santiago de Compostela. \\ A Coruña, Spain
}

\begin{abstract}
Objectives: to determine the prevalence of Helicobacter pylori infection in the general adult population of the province of Ourense.

Material and methods: a cross-sectional study was carried out with a randomly selected populational sample. The diagnosis of Helicobacter pylori infection was reached using the ${ }^{13} \mathrm{C}$-urea breath test.

Results: three hundred and eighty-three subjects were studied, with a prevalence rate of $69.1 \%$ (95\% CI: 61.7-75.1\%); 69.8\% (95\% CI: 63.2-76.6\%) in males and 68.4\% (95\% CI: 61.5-75.4\%) in females (difference not statistically significant). Prevalence increases with age up to a maximum of $88.4 \%$ in the 45-54 years age group, and decreases thereafter to a rate of $57.1 \%$ in individuals over the age of 84 years.

Conclusion: this study reveals that the prevalence rate of $\mathrm{He}$ licobacter pylori infection is high in the general adult population of the province of Ourense. It increases with age until it peaks in the group of middle-aged individuals and is similar in both sexes.
\end{abstract}

Key words: Helicobacter pylori. Prevalence. Epidemiology.

Macenlle García R, Gayoso Diz P, Sueiro Benavides RA, Fernández Seara $J$ Prevalence of Helicobacter pylori infection in the general adult population of the province of Ourense. Rev Esp Enferm Dig 2006; 98: 241-248.

This work was made possible thanks to a grant from the Spanish Foundation of Digestive Pathology.

Recibido: 06-10-05.

Aceptado: 19-12-05.

Correspondencia: Ramiro Manuel Macenlle García. Servicio de Aparato Digestivo. Complejo Hospitalario de Ourense. C/ Ramón Puga, 54. 32005 Ourense. e-mail: macenlle@mixmail.com.

\section{INTRODUCTION}

Some 20 years ago, Warren and Marshall (1) reported the discovery of a bacterium, subsequently named Helicobacter pylori (H. pylori) (2), whose habitat was the human gastric mucosa. Although most infected individuals will never have clinical manifestations, its participation in the genesis of specific disease such as gastroduodenal peptic ulcer or gastric adenocarcinoma has been demonstrated; the development of these specific diseases depends on the interaction between bacterial and environmental factors, as well as host-related factors that have yet to be characterized. This makes it impossible to accurately identify the population at high risk for developing this illness and, hence, to implement prevention programs (3-6). Numerous epidemiological studies have been conducted all over the world with the intention of determining the prevalence of this infection, having estimated that it may affect half of the population worldwide $(5,7,8)$. Many of these studies show relevant methodological limitations, the most common of which being the failure to include randomly chosen individuals from the general population; instead, they generally study blood donors, inpatients, or subjects seen in medical practices, which diminishes the validity of their results $(8,9)$. The current study seeks to determine the prevalence of $H$. pylori infection in the general adult population of the province of Ourense, with the aim of contributing to a better understanding of this infection's epidemiology in Spain.

\section{MATERIAL AND METHODS}

\section{Participants}

A cross-sectional study was carried out in the general adult population (aged 18 years and older) of the province of Ourense, which has some 350,000 inhabi- 
tants registered in the census. Approximately, one third of the population resides in the city of Ourense, and the rest in semi-urban or rural areas. Participants were randomly selected using a table of random numbers applied to a list of 3,000 subjects, obtained in turn by random sampling of the electoral census as published in Boletín Oficial de la Provincia de Ourense (BOP) on October 24, 1998 as a provisional list of individuals eligible for jury duty. The sample size that was needed, 383 individuals, was estimated for a prevalence of infection of 50\% (referenced on prior studies conducted in the Spanish population), considering a 5\% accuracy and a $95 \%$ confidence level (1- $\alpha)$. A letter explaining the nature of the study was mailed or delivered by hand to selected individuals in their homes. Subsequently, attempts were made to contact these individuals and clarify any doubts they might have, inviting them to participate. In the event that consent was obtained, an appointment was made to perform a diagnostic test for $H$. pylori infection at a healthcare center. Participants were included consecutively from December 1999 to June 2002, until an exact sample size was achieved.

The following were considered to be exclusion criteria: a) psychiatric incapacity to comprehend the nature of the study and to perform the diagnostic test; b) physical inability to attend the appointment; c) total or subtotal gastrectomy; and d) use of acid secretion inhibitors in the event that it was impossible to temporarily suspend the use of said medications for four weeks. Individuals who could not be localized, who did not reside in the province, who were deceased, who met exclusion criteria, who were unable to participate for employment reasons, and who refused to participate in the study were considered a loss.

\section{Measures and variables analyzed}

The diagnosis of infection was made on the basis of the carbon-13-labeled urea breath test marketed under the brand name TAU-KIT ${ }^{\circledast}$ (Isomed S.L., Madrid). Carbon13-labeled urea is formulated as a soluble tablet, and 4.2 grams of product are mixed with citric acid in a sachet in the form of a powder to be dissolved in a solution. The test was performed as per the manufacturer's recommendations. In the case of subjects who were under treatment with antibiotics or who had taken them recently, the test was performed four weeks after the last dose had been taken. Those individuals who had received eradication treatment were tested using the breath test if it had not been previously done. The breath test was not performed in people who had received an endoscopic diagnosis of $H$. pylori infection in the preceding months, had not been treated, and whose earlier positive result was deemed valid.

According to the test's technical specifications, sensitivity and specificity for the detection of $H$. pylori is
94.3\% (95\% confidence interval (95\% CI): $87-98 \%$ ) and 94.5\% (95\% CI: 93-98\%)), respectively, for a 4-unit difference in delta values, whereas for a 5-unit difference, sensitivity is $94.3 \%$ (95\% CI: $87-98 \%$ ) and specificity 96.3\% (95\% CI: 93-98\%). A difference in delta values of 5.37 units was used in this study, in light of the local validation study for the breath test with 50 subjects without prior gastric surgery and who were eradication treatmentnaive (unpublished data), thus reaching a sensitivity of 96\% (95\% CI: $80.5-99.3 \%$ ) and specificity of $100 \%$ (95\% CI: 80.5-99.3\%). Samples were analyzed in a clinical laboratory equipped with mass spectrometry (HELCIO-GALIZ. Ourense).

\section{Statistical analysis}

Data were entered into a database using the Access program, and were then analyzed by means of the SPSS version 10.0 and Epidad 2.0 software programs, with a 95\% confidence level. Mean and 95\% CI values were used for quantitative variables, and frequency and percentage were used for qualitative variables. A Chisquared test was used to compare qualitative variables. Significance was established as a $\mathrm{p}$ value $<0.05$.

\section{RESULTS}

In order to study 383 subjects, attempts to localize 1,003 individuals had to be made. It was not possible to find 159 individuals $(15.8 \%)$, mainly due to errors in the data published in the BOP, because such individuals had moved their place of residence, and due to incorrect information characterizing place of residence as rural or urban. Thirty-one individuals (3.0\%) were deceased, 49 (4.8\%) were considered invalid because they met one or more of the exclusion criteria, and it was not possible to contact $109(10.8 \%)$ because they were registered as living outside the province. Two hundred and twenty $(21.9 \%)$ did not choose to participate in the study, and $52(5.1 \%)$ did not participate for employment reasons. The participation rate was considered to be $63.5 \%$ when taking account of those who accepted and those who refused to be analyzed; had the 52 individuals who did not do so for occupational reasons been included in the group of those who refused to participate, the participation rate would have been $58.4 \%$. No statistically significant differences were observed with respect to age and gender between the group of participants and the group of those who were considered lost; nor were statistical differences observed between the group of participants and the group that refused to participate.

H. pylori infection was detected in 265 subjects, $69.1 \%$ of those studied (95\% CI: $61.7-75.1 \%$ ). It is worthy to note that, among participants, 9 had previously been diagnosed and treated; 4 of these diagnoses were 
made by blood testing and 5 by endoscopy. All underwent a breath test, which was negative in 8 of the aforementioned cases. In order to establish the current prevalence rate, these 8 individuals were considered non-infected. Had they not been treated, they would likely continue to be infected, and the prevalence rate in that case would be $71.2 \%$. Mention must also be made of the fact that 2 subjects had been diagnosed with gastric cancer in the previous 12 months; both were positive for infection as determined by histological studies of gastric biopsy specimens. Neither of the two had undergone surgery, nor had they received eradication treatment; hence, they were considered to be infected, and the breath test was not performed.

Three hundred and eighty-three subjects were studied, 196 men $(51.2 \%)$ and 187 women $(48.8 \%)$. Of the 265 infected individuals, 137 were male and 128 were female, with a prevalence rate of infection of $69.8 \%(95 \%$ CI: $63.2-76.6 \%$ ) and $68.4 \%$ (95\% CI: $61.5-75.4 \%)$, respectively. If the 8 subjects who had successfully undergone eradication therapy had been included in the infected group, the figures would have been 144 men and 129 women, with a prevalence rate of 73.4 and $68.9 \%$, respectively. In either scenario, no statistical differences are seen between both sexes.

Mean age of participants was 52.8 years (range: 20-93; 95\% CI: 51.1-54.6) - 54.3 (95\% CI: 52.4-56.2) for the group of infected participants and 49.2 (95\% CI: 45.6-52.9) for the group of uninfected participants. Tenyear interval age cohorts were established: from 25-34 to 75-84, in addition to two extreme groups (an 18-24-year cohort and one for those over the age of 84). In the lowest age group (18-24 years) prevalence rate was $47.1 \%$, increasing in subsequent cohorts until a peak of $88.4 \%$ was observed in the 45-54 year cohort, followed by a decline, which was more pronounced in the age group of those over the age of 84 years, which had a $57.1 \%$ rate of infection (Table I).

Table I. Pravalence of $\boldsymbol{H}$. pylori infection according to age

\begin{tabular}{lcc}
\hline Age & $\begin{array}{c}\text { Number of } \\
\text { subjects }(\%)\end{array}$ & $\begin{array}{c}\text { Prevalence } \\
n(\%)\end{array}$ \\
\hline $18-24$ & $17(4.4)$ & $8(47.1)$ \\
$25-34$ & $53(13.8)$ & $31(58.5)$ \\
$35-44$ & $65(17.0)$ & $39(60.0)$ \\
$45-54$ & $69(18.0)$ & $61(88.4)$ \\
$55-64$ & $62(16.2)$ & $51(82.2)$ \\
$65-74$ & $77(20.1)$ & $55(71.4)$ \\
$75-84$ & $33(8.6)$ & $24(72.7)$ \\
$>84$ & $7(1.8)$ & $4(57.1)$ \\
\hline
\end{tabular}

\section{DISCUSSION}

We present the first epidemiological study on $H$. pylori infection carried out in the province of Ourense, with a population sample taken from the general population. The car- bon-13-labeled urea breath test was used to establish the diagnosis of infection; this test is easy to use and has a high degree of both sensitivity and specificity, thereby enabling us to identify both individuals with active infection and uninfected individuals with great accuracy (10-12).

The percentage of participation, around $60 \%$, can be considered acceptable in order to meet the objective defined for the study. Other relevant epidemiological studies, such as those performed by Gasbarrini et al. (13) in San Marino, Bazzoli et al. (14) in Italy, and Murray et al. (15) in Northern Ireland, report participation rates of 77, 67.9 , and $58.4 \%$, respectively. It is possible that the higher participation rates achieved by these authors versus our study was made possible by the fact the they were carried out in geographically smaller areas with smaller target populations than in our case, making it easier to locate the individuals and to establish a closer relationship between the selected individuals and the investigating physicians.

The prevalence rate obtained, of $69.1 \%(95 \% \mathrm{CI}$ : 61.7-75.1\%), is high if we compare it to studies conducted in Catalonia, the Basque Country, Asturias, Andalusia, and Madrid, with results of approximately 50\% (9,1620 ). Nonetheless, it is below the $84 \%$ obtained in a study carried out in Guadalajara (21), and similar to the 65.6 and $68 \%$ described in the Canary Islands (22) and Cuenca (23), respectively. Reina et al. (24) in Majorca, and Navarro et al. (25) in Vallés Occidental (Catalonia) have described lower prevalence rates $(21.1$ and $38.2 \%$, respectively) when compared to those we detected; however, only four of these studies were conducted with samples taken from the general population, as in our case, which confers greater validity to the results observed $(16,19,21,22)$. The remaining studies were performed using volunteers, blood donors, and inpatients or people who were cared for in medical practices, which imply that the results are not applicable to the general population. Moreover, some of the aforementioned studies did not include individuals with a history of digestive illness, which we believe to be a mistake, since they also are a part of the general population (18). We included 2 subjects with a recent diagnosis of gastric cancer, with histology-confirmed infection, and 9 individuals previously diagnosed with $H$. pylori infection that had undergone eradication therapy. With the exception of the work by Rafols et al. (18), in which the breath test was used, all the other studies were performed using blood tests, different commercially available systems generally lacking prior validation; hence, the results are not easily comparable. With the data derived from comparative studies in hand, their diagnostic precision is less than that achieved with the breath test, with a mean sensitivity of $85 \%$ and a mean specificity of $79 \%$ (11).

Insofar as the prevalence in other countries is concerned, the result obtained is far from the $30.6 \%$ reported for Australia (26), the 32.5\% for the United States (27), or the $39.2 \%$ for Germany (28). It also differs from the 
prevalence rates described for San Marino and Ireland, 51 and $58.4 \%$, respectively $(13,15)$. In contrast, it is closer to the $67.9 \%$ detected for Northern Italy by Bazzoli et al. (14) (who also used the carbon-13-labeled urea breath test) and the $75.9 \%$ reported by Mattana et al. for Argentina (29). Various African nations have also reported very high prevalence rates in both children and adults. Seroprevalence rates of 72 and $76 \%$ were reported in Egypt and Libya, respectively (30,31). Glupczynski et al. (32) found a $77.4 \%$ infection rate in individuals analyzed in Zaire using the carbon-14 breath test, whereas in Nigeria Holcombe et al. (33) detected a seroprevalence rate of 85\%. In Asia, more disparate results have been reported: in India, Graham et al. (34) obtained a prevalence rate of $79 \%$, whereas in China, Taiwan, Nepal, and Vietnam prevalence rates of $44,54.4,56.8$ and $75 \%$, respectively (35-38), have been obtained.

As other authors in our country have described (9, 16), the epidemiological pattern observed is an intermediate one -prevalence rates are neither as low as those found in more developed countries, nor as high as those seen in developing countries. In 9 cases, the infection had been previously diagnosed, and had been successfully treated in 8 . Had they not received treatment, these subjects would have probably continued to be infected, in which case the infection rate would have risen to $71.2 \%$ of participants. Therefore, we can state that medical action can be considered as having induced a slight decline in the number of infected individuals in our area.

We have not detected any differences in prevalence according to gender, which is consistent with the majority of studies in the literature $(9,13-16,20)$. In terms of age, our data also coincide with most published studies conducted in developed countries, in which prevalence is seen to rise until it peaks in middle-aged individuals, around 50-60 years $(9,14,15,18,20)$. In developing countries such as Nigeria, a very high prevalence rate is observed in the young $-82 \%$ in children aged 2 to 9 years, with a slight subsequent increase until it affects $100 \%$ of individuals with 50-59 years of age (33).

In conclusion, this study reveals that there is a very high prevalence rate -close to $70 \%$ - of $H$. pylori infection in the general adult population of the province of Ourense. Prevalence has not been seen to differ according to sex; insofar as age is concerned, prevalence is seen to increase until it peaks in middle-aged individuals, with a gradual decline in the older age cohorts.

\section{ACKNOWLEDGEMENTS}

The authors would like to express their gratitude to Dr. Adolfo Figueiras of Department of Preventive Medicine at Universidad de Santiago de Compostela for his collaboration in the drafting of this manuscript.

\section{REFERENCES}

1. Warren JR, Marshall B. Unidentified curved bacilli on gastric epithelium in active chronic gastritis. Lancet 1983; i: 1273-5.

2. Goodwin CS, Armstrong JA, Chilvers T, Peters M, Collins MD, Sly $\mathrm{L}$, et al. Transfer of Campylobacter pylori and Campylobacter mustelae to Helicobacter gen. nov. as Helicobacter pylori com. nov. and Helicobacter mustelae comb. nov., respectively. Int J Syst Bacteriol 1989; 39: 397-495.

3. Cover TL. Commentary: Helicobacter pylori transmission, host factors, and bacterial factors. Gastroenterology 1997; 113 (Supl. 1): S29-S30.

4. Go MF. What are the host factors that place an individual at risk for Helicobacter pylori associated disease? Gastrenterology 1997; 113: S15-S20.

5. Covacci A, Telford JL, Del Giudice G, Parsonnet J, Rappuoli R. Helicobacter pylori virulence and genetic geography. Science 1999; 284 : 1328-33.

6. Marshall B. Helicobacter pylori: 20 years on. Clinical Medicine 2002; 2 (2): 147-52.

7. Bardhan PK. Epidemiological features of Helicobacter pylori infection in developing countries. Clin Infect Dis 1997; 25: 973-8.

8. Go MF. Review article: natural history and epidemiology of Helicobacter pylori infection. Aliment Pharmacol Ther 2002; 16 (Supl. 1): 3-15.

9. Baena JM, García M, Martí J, León I, Muñiz D, Teruel J, et al. Prevalencia de la infección por Helicobacter pylori en atención primaria: estudio seroepidemiológico. Aten Primaria 2002; 29 (9): 553-7.

10. Savarino V, Vigneri S, Celle G. The $13 \mathrm{C}$ urea breath test in the diagnosis of Helicobacter pylori infection. Gut 1999; 45 (Supl. 1): I18-I22.

11. Pajares JM. Infección por Helicobacter pylori. Rev Clin Esp 2002; 202 (2): 99-110.

12. Gisbert JP, Ducons J, Gomollón F, Domínguez-Muñoz JE, Borda F, Miño G, et al. Validación de la prueba del aliento con 13C-urea para el diagnóstico inicial de la infección por Helicobacter pylori y la confirmación de su erradicación tras el tratamiento. Rev Esp Enferm Dig 2003; 95 (2): 115-20.

13. Gasbarrini G, Pretolani S, Bonvicini F, Gatto MRA, Tonelli E, Megraud F, et al. A population based study of Helicobacter pylori infection in a European country: the San Marino Study. Relations with gastrointestinal diseases. Gut 1995; 36: 838-44.

14. Bazzoli F, Palli D, Zagari RM, Festi D, Pozzato P, Nicolini G, et al. The Loiano-Monghidoro population-based study of Helicobacter pylori infection: prevalence by $13 \mathrm{C}$-urea breath test and associated factors. Aliment Pharmacol Ther 2001; 15 (7): 1001-7.

15. Murray LJ, McCrum EE, Evans AE, Bamford KB. Epidemiology of Helicobacter pylori infection among 4742 randomly selected subjets from Northern Ireland. Int J Epidemiol 1997; 26 (4): 880-7.

16. Rafols A, Solanas P, Ramio G, Suelves N, Rodríguez C, González C et al. Prevalencia de la infección por Helicobacter pylori en atención primaria de salud. Aten Primaria 2000; 25 (8): 104-11.

17. Cilla G, Pérez-Trallero E, García-Bengoechea M, Marimón JM, Arenas JI. Helicobacter pylori infection: a seroepidemiological study in Guipúzcoa, Basque Country, Spain. Eur J Epidemiol 1997; 13: 945-9.

18. Rodrigo L, Riestra S, Fernández E, Fernández MR, García S, Lauret ME. Estudio epidemiológico de la infección por Helicobacter pylori en la población general de Asturias. Rev Esp Enferm Dig 1997; 89 (7): $511-6$.

19. Caballero AM, Sofos S, Valenzuela M, Martín JL, Casado FJ, Guilarte J. Epidemiología de la dispepsia en una comunidad del sur de España. Prevalencia de la infección por Helicobacter pylori. Rev Esp Enferm Dig 2000; 92 (12): 781-6.

20. Martín de Argila C, Boixeda D, Cantón R, Mir N, de Rafael L, Gisbert $\mathrm{J}$, et al. Helicobacter pylori infection in a healthy population in Spain. Eur J Gastroenterol Hepatol 1996; 8 (12): 1165-8.

21. Carballo F, Martínez C, Aldeguer M, García A, Domínguez E, Malfertheiner P, et al. Infección por Helicobacter pylori en Guadalajara: prevalencia y factores asociados. Rev Esp Enferm Dig 1995; 87 (Supl. 1): 7.

22. Castellot A, Santana E, Orengo JC, Peña L, Santana M, Sierra A, et al. Seroprevalencia de la infección por Helicobacter pylori en la Islas Canarias. Rev Esp Enferm Dig 2001; 93 (Supl. 1): 153.

23. González JA, Gómez C, García-Cano J, Nieto J, Morillas J, Pérez JI, et al. Infección por Helicobacter pylori en población sana en la provincia de Cuenca. Rev Esp Enferm Dig 2003; 95 (Supl. 1): 52. 
24. Reina J, Salvá F, Alomar P. Análisis de la prevalencia de anticuerpos anti-Campylobacter pylori detectados en la población humana sana. Rev Esp Enferm Dig 1989; 76 (2): 151-4.

25. Navarro M, Calvet X, Font B, Sanfeliu I, Segura F. Prevalence of Helicobacter pylori infection in the Vallés Occidental, Catalonia. Clin Microbiol Infect 1999; 5 (11): 704-6.

26. Peach HG, Pearce DC, Farish SJ. Helicobacter pylori infection in an Australian regional city: prevalence and risk factors. Med J Aust 1997; 167 (6): 310-3.

27. Everhart JE, Kruszon-Moran D, Pérez-Pérez GI, Tralka TS, McQuillan G. Seroprevalence and ethnic differences in Helicobacter pylori infection among adults in the United States. J Infect Dis 2000; 181: 1359-63.

28. Breuer T, Sudhop T, Hoch J, Sauerbruch T, Malfertheiner P. Prevalence of and risk factors for Helicobacter pylori infection in the western part of Germany. Eur J Gastroenterol Hepatol 1996; 8: 4752.

29. Mattana C, Vega A, Gómez P, Puig de Centorbi O. Serological profile of Helicobacter pylori infection in the population of San Luis (Argentina). Enferm Infecc Microbiol Clin 2004; 22 (4): 227-9.

30. Metwally MA, Kabil SM, Rossignol JF, Montasser NA, Zein CC. A population based study of Helicobacter pylori in Egypt. Gastroenterology 2001; 120 (5): A735

31. Bakka AS, Salih BA. Prevalence of Helicobacter pylori infection in aymptomatic subjects in Lybia. Diagn Microbiol Infect Dis 2002; 43 (4): 265-8.
32. Glupczynski Y, Bourdeaux L, Verhas M, DePerez C, DeVos D, Devreker T. Use of a urea breath test versus invasive methods to determine the prevalence of Helicobacter pylori in Zaire. Eur J Clin Microbiol Infect Dis 1992; 11 (4): 322-7.

33. Holcombe C, Omotara BA, Eldrige J, Jones DM. H. pylori, the most common bacterial infection in Africa: a random serological study. Am J Gastroenterol 1992; 87 (1): 28-30.

34. Graham DY, Adam E, Reddy GT, Agarwal, JP, Agarwal R, Evans DJ et al. Seroepidemiology of Helicobacter infection in India. Comparison of developing and developed countries. Dig Dis Sci 1991; 36 (8): 1084-8.

35. Mitchell HM, Li YY, Hu PJ, Liu Q, Chen M, Du G, et al. Epidemiology of Helicobacter pylori in Southern China: identification of early childhood as the critical period of adquisition. J Infect Dis 1992; 166 : 149-53.

36. Lin JT, Wang JT, Wang TH, Wu MS, Lee TK, Chen CJ. Helicobacter pylori infection in a randomly selected population, heathy volunteers, and patients with gastric ulcer and gastric adenocarcinoma. Scand J Gastroenterol 1993; 28: 1067-72.

37. Kawasaki M, Kawasaki T, Ogaki T, Ito K, Kobayashi S, Yoshimizu $\mathrm{Y}$, et al. Seroprevalence of Helicobacter pylori infection in Nepal: low prevalence in an isolated rural village. J Gastroenterol Hepatol 1998; 10 (1): 47-50

38. Hoang TT, Bengtsson C, Phung DC, Sorberg M, Granstrom M. Seroprevalence of Helicobacter pylori infection in urban and rural Vietnam. Clin Diagn Lab Immunol 2005; 12 (1): 81-5. 